Refereed paper

\section{Investigating the provision of careers information in schools}

\author{
Sarah McNicol
}

\begin{abstract}
A detailed study of careers information provision in secondary schools and its impact on students' decision making in relation to future careers, training and employment is long overdue. Through interviews with Connexions partnerships and case studies in four schools in the West Midlands region, this research aimed to investigate how careers information (in the library and elsewhere) can be provided most effectively in schools to ensure it is accessible and useful to students. Although the time allocated within the curriculum for careers education is being reduced and not all students are now automatically entitled to a careers interview, few students are likely to spend time investigating careers independently. Even careers libraries or information centres which are attractive and well stocked are not well-used by students. The skills of library staff might be harnessed more effectively than is the case at present to help to improve careers provision in schools.
\end{abstract}

\section{The Author}

Sarah McNicol is a researcher at evidence base research and evaluation services at the University of Central England in Birmingham.

\section{The Occasion}

Elsevier/LIRG Research Award 2004

\section{Introduction}

The provision of high quality careers information, and support in its use, is vital to help students to develop the skills they need to become self-directed decision-makers with regard to their own careers. Connexions, the government's support service for all young people aged 13 to 19 in England, is expected to provide access by students to impartial information and guidance on learning and career options, including through a school's careers/Connexions library. However, the standard of careers library provision can vary considerably between schools. Some have a dedicated room with a wide range of accessible resources, while others are relegated to the corner of an office. Morris et al (2001) found that the gap between schools with good and poor careers provision has, in fact, widened since the late 1990s. The National Survey of Careers Education and Guidance (Ofsted, 1998) showed that $10 \%$ of schools lacked a dedicated careers library and that in one-quarter, the quality of careers information was unsatisfactory. Access to the library was poor for one in four students and over half of all schools did not make effective use of ICT. Although careers education became mandatory under the 1997 Education Act, there are still no official standards relating to the provision of careers libraries and information services.

The effectiveness of careers provision in schools will depend on how effectively the three components of careers guidance, education and information are combined. Guidance refers to activities offered on a one-to-one or small group basis which enable individuals to apply their career learning and development to the construction and management of their own careers; careers education refers to teaching and learning activities, usually provided in group settings, which facilitate the career learning and development of young people; and careers information refers to activities requiring information skills, usually provided in a careers library, and involving access to a wide range of resources and media which improve the careers knowledge of young people (Barnes et al, 2002). It is important that all three of these are studied. A detailed study of careers information 
provision in secondary schools and its impact on students' decision making in relation to future careers, training and employment is long overdue. Although some studies have been carried out into the effectiveness of careers guidance in schools, higher education and for adults (eg Bayliss, 1999 and Miller and Brotherton, 2001), careers libraries have long been neglected by researchers.

\section{Methodology}

The aim of this research was to investigate how careers information (in the library and elsewhere) can be provided most effectively in schools to ensure it is accessible and useful to students and assists them in making decisions about careers and further education. The research had five objectives:

1. to identify the advantages and disadvantages of various formats of careers information (eg different media)

2. to identify how careers information can be arranged and managed to cater for the needs of students

3. to consider how the role of careers information provision relates to students' selfdirected sessions, careers education lessons and careers guidance in schools.

4. to examine the impact of the introduction of Connexions on careers information provision in schools

5. to account for variation in careers information provision between schools and to highlight examples of good practice.

The first stage of data collection took the form of interviews with Connexions representatives from three West Midlands partnership areas. The West Midlands is a diverse region which includes both urban and rural areas; a broad ethnic mix; and localities with varying social and economic circumstances. Within this region, three Connexions partnership areas, Birmingham \& Solihull, Herefordshire \& Worcestershire and Staffordshire (including the unitary authority of Stoke-on-Trent) were selected to reflect urban and rural localities and areas with differing socio-economic characteristics. Interviews with Connexions representatives were carried out to obtain details about the information provision, as well as guidance services, they offer. Interviewees were asked to comment on their impressions of the overall standard of careers information provision in their Partnership area and the extent of variation between schools.

Within two of these Connexions partnership area, a sample of two schools was chosen based on details provided by Connexions representatives. These were chosen to be representative of different types of schools in terms of catchment area, size and type of school and careers provision. The precise format of the data collection varied between schools to cope with factors such as timetable constraints and staff availability, but each involved some or all of the elements described below:

a. Interview with the school's careers coordinator: Careers co-ordinators were asked about their role and how this relates to support provided by other staff in the school and Connexions; how the careers library is managed (eg updating, ensuring materials are relevant to the curriculum); their use of the careers information in careers education; the ways in which they believe careers information provision supports students; and how the needs of individual students are catered for.

\section{b. Interview with the school's Connexions} adviser: Advisers were asked about their role and how this relates to support provided by the school; their use of the careers information in guidance activities; and the ways in which they believe careers library and other information provision supports students.

\section{c. Interview $(s)$ with other school staff involved} in careers library provision eg librarian: Other school staff were asked about their role; how the careers library is managed; the use made of the careers library; and the ways in which they believe careers information provision supports students.

\section{d. Interviews with teachers responsible for the} delivery of careers education: In some schools it was possible to carry out short 
interviews with teachers responsible for delivering careers education to find out what use they make of the careers library and other information resources in lessons; how they encourage students to make use of resources; and what difficulties they felt students experienced in finding and using careers information.

e. Focus groups with students from Years 9, 10, 11 and 13 (13-14, 14-15, 15-16 and 17-18 year olds respectively): Between one and three focus groups were held in each school and the number of students ranged from three to twelve. The focus groups aimed to discover:

- what use students make of the careers library and other information resources eg ICT (in self-directed sessions, in lessons and in guidance activities)

- reasons for non-use of the careers library/information

- the type of information they require and the information they find

- their views of the careers library and CEG generally e.g. ease of use, opening times, resources available, overall image

- what factors had influenced their future career and educational plans and ambitions

- what factors motivate them to use careers information

- problems they have experienced in accessing information and identifying and obtaining materials which match their needs.

\section{Background to the research}

According to the non-statutory National Framework for Careers Education and Guidance (CEG) in England, "Careers Education and Guidance programmes make a major contribution to preparing young people for the opportunities, responsibilities and experiences of life. They help young people make transitions as learners and workers" (DfES, 2003). The two components, education and guidance, are interrelated, with education helping to equip young people with the knowledge and skills to make successful choices, and guidance enabling them to make use of these skills to make decisions which are right for them. In relation to information and information skills, one of the learning outcomes for students at Key Stage 3 is to "acquire the knowledge, understanding and skills to identify and use a variety of sources of careers information, including ICT [and] use information handling and research skills to locate, select, analyse, integrate, present and evaluate careers information relevant to their needs". At Key Stage 4, students are expected to acquire "the knowledge, understanding and skills to identify, select and use a wide range of careers information and distinguish between objectivity and bias". At Post-16 level, students are expected to acquire "the knowledge, understanding and skills to make critical use of a range of information sources to explain how careers are changing [and] obtain careers information relevant to personal needs and process it effectively (DfES, 2003).

The Connexions Service was launched by the Department for Education and Skills (DfES) in April 2001. The service aims to provide integrated advice, guidance and access to personal development opportunities for 13 to 19 year olds in England and to help them make a smooth transition to adulthood and working life. Connexions is delivered through local Partnerships which cover the same geographical areas as the Learning and Skills Councils. Connexions offers differentiated and integrated support to young people. All young people have access to a personal adviser. For some, this may be just for careers advice, but for others it may involve more in-depth support to help identify barriers to learning and to broker access to more specialist support. Personal advisers work in a range of settings, schools, colleges, one-stop shops community centres and on an out-reach basis. Connexions provides, or is developing, a range of ways for young people to access information, including telephone, the web, online chat, email and text messaging.

A major problem is that there are fewer personal advisers than was envisaged when the Connexions Service was being planned, so schools and colleges have to play an important a 
role in providing advice. However, many schools feel they do not have the capacity to provide appropriate levels of guidance for young people (DfES, 2004). The future of the Connexions service is currently in doubt. There are questions about whether it can adequately fulfil its dual role of supporting socially excluded young people along with careers guidance for all teenagers given its current level of funding (Ward, 2005).

All state-funded schools must work with Connexions to "ensure students have access to guidance materials and a wide range of up-todate reference materials relating to careers education and careers opportunities. Where possible, this information should be provided in a dedicated Connexions resource centre/library with computer-based resources; where this is not possible, a school should work with their local Connexions to provide the next best form of provision which satisfies students' information needs...Advice and support (including resources) for the Connexions resource centre/library should form part of an annual Partnership Agreement between the school and the Connexions service" (teachernet, 2004). As Champney et al state, the increased time and space required to maintain a Connexions information centre, rather than a simple careers library, is a common concern (Champney et al, 2004: 4). They argue that the worst information centres are those which:
- Have too much information

- Have too little information (ie no choice)

- Are messy and disorganised

- Are too uniform and do not encourage use

- Are inconsistent in the way information is organised and displayed.

On the other hand, the best information centres are those which:

- Have an easy-to-understand display system

- Help users to find what they need

- Use a system of colours/symbols/icons to identify the different resources and information areas

- Include a range of seating and work areas

- Are clean, tidy and inviting

- Have regularly changed wall displays

- Respond to the needs of users.

Champney et al (2004) recommend the use of ICT resources as these are favoured by OFSTED (the Office for Standards in Education); often offer additional features such as access to password protected websites; are popular with students; and require less display space. In addition, information should be provided in the form of videos, books, magazines, newspapers and periodicals. They also recommend that, when reviewing the physical facilities of the information centre, particular attention should be paid to the display system and accessibility. Information needs to be displayed in "an easy-to-use and nonthreatening style) if materials are to be wellused" (Champney et al, 2004).

\section{The case study schools}

All four case study schools were mixed comprehensives, but varied in many ways including specialism, size, age range and GCSE pass rate. This is illustrated below.

\begin{tabular}{|l|l|l|l|l|l|}
\hline $\begin{array}{l}\text { Name of } \\
\text { school }\end{array}$ & $\begin{array}{l}\text { Connexions } \\
\text { Partnership }\end{array}$ & Specialism & $\begin{array}{l}\text { Number of } \\
\text { students } \\
\mathbf{( 2 0 0 4 )}\end{array}$ & $\begin{array}{l}\text { Age range } \\
\text { of students }\end{array}$ & $\begin{array}{l}\text { \% 5 or more } \\
\text { A*-C grades } \\
\text { at GCSE } \\
(\mathbf{2 0 0 4})\end{array}$ \\
\hline School A & Staffordshire & Engineering & 1099 & $11-16$ & $39 \%$ \\
\hline School B & $\begin{array}{l}\text { Herefordshire } \\
\& \\
\text { Worcestershire }\end{array}$ & Technology & 1220 & $12-18$ & $62 \%$ \\
\hline School C & Staffordshire & Arts & 941 & $11-18$ & $60 \%$ \\
\hline School D & $\begin{array}{l}\text { Herefordshire } \\
\&\end{array}$ & Languages & 879 & $13-18$ & $45 \%$ \\
\hline & Worcestershire & & & & \\
\hline
\end{tabular}

Table 1: Key characteristics of the case study schools 
The following section discusses careers information provision in each school.

\section{School A}

At School A, the careers library is located within the main school library, which is also a dual use public library, but relatively few resources are kept in the library; most of the schools' careers information resources are housed elsewhere such as the Connexions interview room. The resources which are in the library are split between two areas, with the reference books such as Occupations being separate from leaflets, booklets, videos, magazines, CD ROMs and prospectuses. There are also a small number of general books about careers in the public library as well as leaflets on other Connexions topics such as health and legal rights. The careers section of the library is not well-used. According to the careers coordinator and the school librarian, the heaviest use is made of the army leaflets, Occupations reference book and the Working in... series ${ }^{1}$. The library is some distance from the coordinator's office and from the Connexions interview room, so the co-ordinator is considering setting up an additional mini-library in this area of the school. Students at School A tend to make greater use of ICT than print resources to find out about possible careers and further education. There is plentiful ICT access as the school has five dedicated PC rooms as well as access in the library which is a joint school and public library and has more than 30 PCs in total. One of the main ways in which students at School A found out about careers and further education opportunities was using computer software. They found programs such as $\mathrm{CID}^{2}$ useful to find out what types of jobs they might be suited to. As well as using PCs during the allocated tutorial time, students sometimes made use of these programs in their own time.

\section{School B}

The careers library at School B is a small room adjoining the careers co-ordinator's office and teaching room. It has a range of printed leaflets and books covering all the main areas of careers information. The majority of information relates to careers rather than broader
Connexions issues. There is also a PC with careers software and space for the Connexions adviser to conduct interviews. The library is open four lunchtimes a week, but is not particularly well-used. Some of the students felt that this was because it is out of the way and not well-publicised. University prospectuses for the current year are kept in the Sixth Form area and the previous year's are available in the careers library. In addition, some careers information is kept in the main school library; a portion of the library budget is allocated for careers and this is managed by the school librarian. The careers library itself is funded with the help of a grant from the local Connexions Partnership in addition to school capitation, but the budget is quite limited which can make it difficult to afford more expensive items. The school tends to keep resources for four years rather than the recommended two partly for this reason. The careers co-ordinator is supported by a classroom assistant and a student-librarian has responsibility for maintaining the careers library and helps other students using the PC.

The school has a site licence for Odyssey ${ }^{3}$ which is the main computer program used. This is available to all students in the library and CEG teaching room at break and lunchtimes. The careers co-ordinator pointed out that, with more information available over the Internet, there was less need to have so many paperbased resources. Online materials are easier to update and cheaper to produce, but in schools without plentiful computer access, such as School B, it can be difficult to ensure students have access to these, either as a whole class or individually. The careers co-ordinator had found that online resources were particularly popular with less able students, but they often have difficulty in understanding the information and require more background information and support than is often given.

\section{School C}

There are two areas where careers resources are housed at School C: the main library and the Connexions interview room. The careers coordinator has a budget to buy careers resources, but seeks the advice of the Connexions adviser. The school also has money for software from 
the local education-business partnership. The Connexions library has three PCs and a wide range of books which are used, primarily, during interviews or small group activities led by the Connexions personal adviser and the school's Learning Mentors. The majority of resources are placed in here. Students sometimes use the Connexions room at break and lunchtimes to look for information, but the Connexions adviser and careers co-ordinator both believe that this could be encouraged more. In the main school library there is an area with coffee tables and low chairs where there are a few books and magazines as well as the college and university prospectuses. Unsurprisingly, these are particularly popular with the Sixth Form. Kudos $^{4}$ is networked throughout the school and is available in the library. Fast Tomato ${ }^{5}$ is also widely used and appeared to be popular with students. For the Sixth Form, a gap year CD ROM is available and there is a noticeboard in the Sixth Form area to inform students of sponsorship opportunities, courses available and similar information.

\section{School D}

Careers resources at School D are housed in the Additional Learning Facility (ALF) which was opened two years ago and is managed by a librarian. Sixth form students use the ALF during their study periods and younger students have access at breaks, lunchtimes and after school. They are able to take books home or to ask for photocopies of reference materials. The Careers Information Area accounts for a significant proportion of the materials in the ALF. There are up-to-date prospectuses for universities and local colleges as well as books and leaflets. In addition to materials on the shelves, there are resources in magazine racks around the room and careers-related displays to attract students. There are also banks of computers with access to careers programs, Kudos, CID and Key Clips 6 . These programs are networked and available on all PCs in the school. The careers department has a webpage with links to useful sites such as the Connexions website, but most students said they prefer to search on Google despite the fact that this can present them with an overwhelming amount of information. All books and similar careers resources are housed in the ALF and crosscurricular posters are usually passed on to the relevant departments.

The librarian has little direct involvement in the careers library. The careers co-ordinator selects the resources at the county's careers resources fair and by carrying out an audit of materials. Some of the money is spent on teaching materials and the remainder goes to ensure that the careers information area has at least the minimum level of resources and that these can be displayed effectively. The Connexions service visits the school to weed and reclassify the stock.

\section{Conclusion}

The students interviewed in this research were generally happy with the careers information available to them at all schools; there was not a significant demand for more resources.

However, it was apparent that only those students who are conscientious and have clear career plans are likely to spend time outside lessons thinking about and researching careers. Most want information easier and quickly without a great deal of effort. This is a problem because little time is allocated for Careers Education and Guidance in most schools and not all students may have a Connexions interview, so students really need to be encouraged to carry out research in their own time.

Sadly, even careers libraries or information centres which were attractive and well stocked were not well-used by students. Perhaps more could be done to publicise their availability in some cases, but in general students had little interest in printed materials. Few students make use of careers libraries or information centres except during lessons or guidance sessions.

It would appear that Connexions has had very little effect on the information and guidance provided in schools; this has remained essentially careers-focussed. Where Connexions has had an impact is in the fact that students felt to require more support are targeted. Several careers co-ordinators felt that 
this meant that the middle and higher ability students were not getting the support they might need. In these circumstances it is even more crucial that students make the effort to investigate career options outside lessons.

In relation to CEG, students in all schools expressed a strong preference for practical activities which allowed them to explore, gain experience and investigate for themselves. This meant that work experience, visits, talks by outside bodies and interactive computer programs were all seen as valuable. More passive forms of learning such as reading printed materials were less popular. The advantages and disadvantages of the main types of careers information used by students are outlined below.

\section{Printed materials:}

Books, leaflets and other printed materials were not liked and rarely used by students. The only exception to this was use of university prospectuses by Sixth Form students.

Otherwise, they were seen as boring and rather old-fashioned.

\section{ICT}

ICT resources were much more popular than print. In addition to specific careers programs such as CID, Odyssey and KUDOS, many students searched the Internet for information about careers and educational opportunities. Among Sixth Formers, ICT was used to find out about universities, and various websites and computer programs were also used by Connexions advisers in guidance interviews. ICT has a number advantages over printed materials, including the fact that it can be updated regularly, which is important for careers information. It can of course be networked and made available throughout a school.

Furthermore, OFSTED appears to favour ICT provision over traditional paper-based materials.

However, a major problem with ICT is information overload. Students are clearly in need of more guidance when using electronic information sources, especially the Internet, although even programs like Kudos were criticised by students for giving them too much information. The availability of PC terminals is another difficulty in many schools; this can limit access to careers information rather than widening it up to pupils.

\section{People}

People who could act as sources of information might include family, friends, teachers, outside speakers and Connexions advisers. Family, especially parents and older siblings, were one of the most important reference points for students because they were trusted. However, outside speakers were also highly regarded for their first hand knowledge of working or educational environments. Students felt that hearing information from people was more interesting than a reading book or computer screen.

The fact that students trust information and advice about careers they receive from parents and other relatives should be capitalised on. The danger of such individuals giving illinformed or biased advice also needs to be avoided. This means that providing appropriate information about career and education choices for parents is crucial. Most schools make efforts to ensure that this is the case, for example, local colleges are often represented at open evenings, but perhaps more could be done.

\section{Personal experience}

As well as learning from other people, students particularly valued experiencing work or further education themselves. Work experience can be useful to stimulate Year 10 students to start to think more seriously about careers and can provide valuable experience in their chosen field or demonstrate options they may not have considered. However, work experience did not seem to be particularly useful in assisting many students to make career decision in the long term; it was not as highly valued by Sixth Formers as it was by Year 11 students. A major problem with work experience is that students are reluctant to take the initiative and need support in organising their placement. Organising placements is extremely timeconsuming for careers co-ordinators. Residential stays at universities are also important as they can encourage students who would not otherwise do so to apply 
Another way in which students' personal experience is important is through hobbies and leisure interests which can provide students with possible career options. Similarly, school subjects students are good at can provide a basis for career decisions. Students were more concerned about doing something they had a genuine interest in than something that was well-paid.

Examples of good practice in the provision of careers information in schools observed in this research included:

- making careers computer programs available across the school network

- the use of good display techniques for careers literature eg face-on displays in magazine racks and attractive displays

- residential stays at local universities for Year 11 students

- the use of outside speakers as a key part of the CEG programme

- visits to outside organisations and events eg careers fairs

- the presence of local colleges at open evenings and parents' evenings

- having a specialist CEG delivery team who have developed skills in this area

- plentiful day release and work experience opportunities

- providing activities and information to support parents in guiding their child's career choices

- activities to start students thinking about career options from an early age.

Although Connexions representatives interviewed felt that the standard of careers information provision varied considerably between schools, there was little difference to be seen in the case study schools. This may be because those who agreed to participate in the research were more interested in CEG and better organised in this respect. All the careers libraries visited were fairly well-stocked, although access to information was a slight problem in some cases. In terms of ICT resources, too, the schools were well-organised and resourced with careers programs being available across the school network. The only variation in this respect related to PC provision for the school as a whole.

One way in which the case study schools did differ was in their different approaches to CEG delivery. Having a specialist team generally felt to be a better approach, but even where CEG was delivered in this way, it was still difficult to organise training or departmental meetings.

The specialism of the schools (eg languages, technology) had very little effect on careers information provision, although some did have specific resources or events relating to the specialism. However, local conditions, such as the major industries and employers in the locality and the community's attitudes towards higher education could have an impact of the delivery of CEG in schools.

It was worrying that, in this research, none of the case study schools were making full use of the skills of their librarian in relation to careers information provision. Library staff rarely played a key role in updating or organising the careers library or the provision of electronic resources and had no role in other informationrelated events. This is a missed opportunity for both schools and the library profession.

\section{Recommendations}

The research made a number of recommendations about how careers library and information provision within schools might be improved.

- Within schools, librarians need to work more closely with career co-ordinators, Connexions advisers and other key players to investigate how they can best contribute to supporting careers information provision in schools (eg maintaining a list of useful websites, promoting the use of the careers library and other resources, assisting in brokering links with employers and professional organisations).

- At a practical level, schools should ensure that careers computer programs are networked throughout the schools and that adequate access is provided for all pupils. 
Connexions (or schools) should compile and maintain a list of approved careers-related websites and ensure that this is well publicised to teachers and students. Such lists should be shared between schools rather than each school duplicating the work.

- ICT should be used to promote greater discussion and communication about careers matters among students, teachers, parents, Connexions staff, librarians, employers, colleges, universities and other interested stakeholders. Students clearly value and trust information provided by people rather than anonymous books or websites. This could be capitalised on by using ICT to provide a secure environment in which students can interact with information and guidance providers such as colleges and employers as well as Connexions advisers more interactively than is often the case at present. ICT can enable students to communicate with a much wider range of people who can present them with a greater variety of careers options than is possible through personal visits alone.

- To provide students with the skills to investigate careers options independently, and encourage them to do so, school librarians should develop information skills sessions for students based around evaluating careers information, for instance the importance of information being up to date and reliable. Teaching students these techniques is especially important given the fact that many are coming to rely on information they find on the Internet, usually relying on searching using Google rather than lists of recommended sites provided by schools or Connexions. This is a crucial area where the librarian's professional skills are rarely exploited at present.

- Adequate provision needs to be made for the training and development of teachers responsible for CEG delivery. Where CEG is delivered by non-specialist teams, schools should consider whether this is the best approach.

- Schools (working with Connexions, employers and local colleges) should ensure that adequate information is provided for parents to help them to advise their child about career decisions.

- More education-business links are needed to make it is easier to organise visits by outside speakers who are prepared to share their experiences as well as events such as careers conventions and mock interviews. More links are also needed between schools and universities and colleges to allow more visits and residential stays to give students a better idea of what being at a university or college is like. Furthermore, better links are needed between schools and employers and colleges to expand Young Apprenticeship and similar schemes to give more students practical experience in the work place while they are still at school.

- Finally, to improve the information available to young people, publishers of careers reference books which are regularly updated should investigate the possibility of making their resources available online. Software developers should ensure that careers software is differentiated and caters for students' individual needs, especially the less able.

A copy of the full report is available at http://www.ebase.uce.ac.uk/docs/Careers Info $\underline{\text { Schools Report.doc }}$ 


\section{Notes}

1 The 'Working in' Series insight into what it is like to work in a particular field. They are based on interviews with those already working in these areas.

2 A package aimed at the younger age range. It contains information about a wide range of careers which can be accessed either alphabetically, via favourite school subjects, interests, or exam levels. There is also a quiz to help generate jobs suggestions and many of the careers in the database contain pictures and video clips.

3 A database of careers information.

4 This package can be used to generate job ideas for those aged 14-20. It matches responses to questions on aspects of work and produces a list of job suggestions. It also has a comprehensive database of careers information which can be used whether or not the career matching facility is used.

5 See http://www.fasttomato.com

${ }^{6}$ The program generates a list of CLIPS leaflets, allows them to call up leaflets on screen and print them off.

\section{References}

Barnes, A., Donoghue, J., and Sadler, J. (2002) Improving Careers Education: An analysis of recent research and inspection findings, Careers Education Support Programme.

Bayliss, V. (2000) “Joined-Up Guidance:Where Do We Go from Here?" CeGS Occasional Paper, Derby: Centre for Guidance Studies, University of Derby.

Champney, Jan, Dixon, Alison, Kroto, Margaret et al (2004) CIOLA: The New CIOLA Directory 2004/5, $19^{\text {th }}$ edition, Richmond: Trotman and Company.

Department for Education and Skills (DfES) (2004) Connexions Service, Advice and Guidance for All Young People, London: The Stationery Office.

Department for Education and Skills (DfES) (2003) Careers Education and Guidance in England, A National Framework I I-19, London: DfES.

Miller, R. and Brotherton, C (200I) "Expectations, recall and evaluation of careers guidance and interviews by students and careers advisers: a preliminary study", British Journal of Guidance and Counselling 29(I), Pp. 95-II0.

Morris, M., Rickinson, M., and Davies, D. (200I) The Delivery of Careers Education and Guidance in Schools, London: DfES.

Office for Standards in Education (1998) National Survey of Careers Education and Guidance, London: OFSTED.

Teachernet (2004) A to Z of School Leadership: Careers education and guidance URL: http://www.teachernet.gov.uk/management/atoz/C/care erseducationandguidance [Accessed I I.I I.04]

Ward, Lucy (2005) "Careers and guidance service may be replaced", The Guardian, 2 Feb, URL: http://education.guardian.co.uk/schools/story/0, , 140376 8,00.html [accessed 8.3.05]. 